\title{
ANALISIS VALUASI NILAI WAJAR SAHAM PT. ADARO ENERGY TBK MENGGUNAKAN METODE FREE-CASH FLOW TO FIRM (FCFF)
}

\author{
Ecryna Cyntia Hutapea ${ }^{1}$ \\ PT. Maven Lab \\ Tyara Pratiwi Poernomoputri \\ Al Azhar Univerisity \\ Pardomuan Sihombing ${ }^{3}$ \\ Recapital Aset Management
}

\begin{abstract}
PT Adaro Energy Tbk, an Indonesian private company engaged in coal mines and became the largest thermal coal producers both in Indonesia, which also operates coal mines and have the single biggest in the southern hemisphere. Coal products PT Adaro Energy Tbk has medium levels of energy content, and assign its trademark with the name of the Envirocoal. PT Adaro Energy Tbk is officially listed on the Indonesia Stock Exchange (BEI) on July 16, 2008 and was recorded as the largest company in the history of the Stock Exchange for deals done in rupiah (whereas in the US $\$$ is the currency of the latter), and an IPO $4^{\text {th }}$ largest for the year 2008 in Asia (excluding Japan) with a stock offering as much 11.139331 billion shares. To assess the stock price of PT Adaro Energy Tbk in the market, the valuation of shares is needed, where the valuation of these shares will be known intrinsic value (fair price). The method used in this valuation is the Discounted Cash Flow method using the model of Free Cash Flow to Firm. Valuation results would be very useful to be used as the basis for making investment decisions to buy, hold or sell stock. Based on the calculation that stock valuations have been carried out, obtained the intrinsic value of PT Adaro Energy Tbk amounting

\footnotetext{
${ }^{1}$ PT. Maven Lab (rynaecryna@yahoo.com)

${ }^{2}$ Al Azhar University (tyarapratiwi@yahoo.co.id)

${ }^{3}$ Directror of Recapital Aset Management (pardomuan_sihombing@yahoo.com) 
to Rp 1,570 while the price of shares in PT Adaro Energy Tbk as at July 6, 2012 is \$ 1,866, with the conclusion of the stock price of PT Adaro Energy Tbk undervalued or is below the market price.

Keywords: valuation, intrinsic value, market value, discounted cash flow, free cash flow to firm, overvalued, undervalued.

\begin{abstract}
ABSTRAK
PT Adaro Energy Tbk merupakan perusahaan swasta Indonesia yang bergerak dibidang tambang batu bara dan menjadi produsen batu bara termal terbesar kedua di Indonesia yang juga mengelola serta memilki tambang batubara tunggal yang paling besar di bumi bagian selatan. Produk batu bara PT Adaro Energy Tbk memiliki kadar kandungan energi sedang, dan menetapkan merek dagangnya dengan nama Envirocoal. PT Adaro Energy Tbk secara resmi tercatat di Bursa Efek Indonesia (BEI) pada tanggal 16 Juli 2008 dan tercatat sebagai perusahaan terbesar dalam sejarah BEI untuk penawaran yang dilakukan dalam mata uang rupiah (sedangkan dalam mata uang AS\$ adalah yang kedua), dan merupakan IPO terbesar ke-4 untuk tahun 2008 di negara Asia (selain Jepang) dengan penawaran saham sebanyak 11.139.331.000 lembar saham. Untuk menilai harga saham PT Adaro Energy Tbk di pasar, maka diperlukan valuasi saham, dimana dengan valuasi saham ini akan diketahui nilai intrinsiknya (harga wajar). Metode yang digunakan dalam valuasi ini adalah metode Discounted Cash Flow dengan menggunakan model Free Cash Flow to Firm. Hasil valuasi akan sangat bermanfaat untuk dijadikan sebagai dasar pengambilan keputusan investasi baik membeli, menahan atau menjual saham. Berdasarkan hasil perhitungan valuasi saham yang telah dilakukan, didapat nilai intrinsik PT Adaro Energy Tbk sebesar Rp 1.570 sementara harga saham PT Adaro Energy Tbk per tanggal 6 Juli 2012 adalah Rp 1.866, dengan kesimpulan harga saham PT Adaro Energy Tbk undervalued atau berada dibawah harga pasar.
\end{abstract}

Kata kunci: valuasi, nilai intrinsik, nilai pasar, discounted cash flow, free cash flow to firm, overvalued, undervalued. 


\section{PENDAHULUAN}

\section{Latar Belakang Masalah}

Pasar modal memiliki peranan penting bagi perekonomian suatu negara, dimana secara ekonomi makro, pasar modal dapat berfungsi sebagai sarana dalam pemerataan pendapatan. Bagi investor, pasar modal merupakan tempat berinvestasi yang menarik karena dapat memberikan return yang sesuai dengan preverensi resiko mereka. Sedangkan bagi emiten, pasar modal dapat memberikan alternatif pemenuhan kebutuhan pendanaan melalui IPO.

Berdasarkan data World Coal Association (WCA) tahun 2010, Indonesia merupakan negara yang menduduki peringkat ke-7 sebagai produsen batu bara terbesar di dunia dan merupakan negara eksportir ke-dua setelah Australia.

Beberapa negara tujuan ekspor batu bara Indonesia adalah Cina, India, Jepang, Kenya, Bangladesh, dan Pakistan.

Menurut Direktur Asosiasi Pertambangan Batu Bara Indonesia, pada tahun 2012 diperkirakan Negara Cina dan India akan menyerap sekitar 80 metrik juta ton batu bara Indonesia (Subkhan, A.S, 2012).

Kebutuhan batu bara diprediksi akan semakin meningkat dengan adanya Peraturan Presiden Republik Indonesia Nomor 5 tahun 2006. Tujuan dibuatnya peraturan ini adalah untuk mengamankan keberadaan pasokan energi nasional dan tercapainya bauran energi yang optimal pada tahun 2025.

Di BEI terdapat 17 perusahaan tambang batu bara yang tercatat, dan salah satu diantara perusahaan itu adalah PT Adaro Energi Tbk. PT Adaro merupakan perusahaan tambang batu bara terbesar kedua di Indonesia, produk batu bara yang dihasilkan oleh perusahaan memiliki konten sulfur dan kadarabu yang lebih rendah dan memiliki brandingenvirocoal(Wicaksono, R. A, 2011).

Pada tahun 2011, PT Adaro melakukan akuisisi pada PT Mustika Indah Permai (MIP) melalui anak usaha perusahaan yaitu PT Alam Tri Abadi. Dengan adanya akuisisi MIP, memungkinkan PT Adaro untuk dapat mencapai target produksi sebesar 80 juta ton. 
Upaya-upaya strategis harus dilakukan oleh tiap perusahaan tambang batubara Indonesia agar dapat menghadapi persaingan dan meningkatkan value perusahaan.

\section{Identifikasi Masalah}

Bagi investor berinvestasi di pasar modal, khususnya saham memiliki resiko yang cukup tinggi mengingat karakteristik yang dimiliki oleh instrumen keuangan tersebut yaitu high risk high return, sehingga para investor harus memiliki tingkat ketelitian yang baik saat akan mengambil langkah untuk melakukan investasi. Saham dapat memberikan investor keuntungan, namun bisa juga memberikan kerugian, karena harga saham yang sangat mudah berubah (fluktuatif). Oleh sebab itu, sebelum memutuskan untuk berinvestasi pada suatu saham, investor sebaiknya melakukan analisis valuasi saham terlebih dahulu untuk mengetahui intrinsic value.Penelitian ini akan berfokus terhadap valuasi saham PT Adaro Energy Tbk dengan menggunakan pendekatan discounted cash flow valuation yaitu metode free cash flow to firm (FCFF).

\section{Tujuan Penelitian}

Melanjutkan pembahasan dari identifikasi masalah, tujuan dari penelitian ini adalah sebagai berikut :

1. Melakukan valuasi dengan menggunakan metode discounted cash flow valuation yaitu free cash flow to firm (FCFF) untuk dapat mengestimasi intrinsic value saham PT Adaro Energi Tbk dan membandingkannya dengan harga saham perusahaan di pasar, sehingga dapat diketahui apakah harganya undervalued atau overvalued.

2. Melakukan perbandingan kinerja PT Adaro Energi Tbk dengan pesaingnya (competitor) melalui analisis rasio-rasio.

\section{Ruang Lingkup Penelitian}

Analisis intrinsic value ini akan menggunakan metode valuasi discounted cash flow valuation yaitu free cash flow to firm (FCFF) dengan memakai data laporan keuangan perusahaan dari tahun 2007 s/d 2011. 


\section{Sistematika Penelitian}

Penulisan penelitian ini terdiri dari 5 bab, yaitu pendahuluan, landasan teori, metodologi penelitian, pembahasan, dan hasil analisis, kesimpulan dan saran.

\section{LANDASAN TEORI}

\section{Pendahuluan}

Untuk mendapatkan intrinsic value saham perusahaan, dapat digunakan analisis fundamental maupun teknikal dengan pendekatan top-down approach (dari atas ke bawah) maupun bottom-up approach (dari bawah ke atas). Untuk penelitian ini, analisis yang digunakan adalah analisis fundamental dengan pendekatan top-down approach, yaitu diawali dengan analisis ekonomi makro, analisis industri, dan analisis perusahaan untuk menentukan intrinsic value saham perusahaan.

\section{Analisis Ekonomi Makro}

Analisis ekonomi makro dapat memberikan gambaran mengenai kondisi kinerja perekonomian suatu negara dengan menggunakan indikator-indikator seperti produk domestik bruto, tingkat inflasi, dan tingkat suku bunga. Analisis ekonomi makro ini dilakukan karena adanya pengaruh dari kondisi ekonomi makro terhadap kondisi pasar secara umum serta performa saham tersebut secara khusus.

\section{Produk Domestik Bruto}

Menurut Miles, D., Scott A., (2005), Gross Domestic Product (GDP) adalah suatu cara pengukuran pertumbuhan ekonomi yang paling lazim digunakan. GDP dapat dihitung dari jumlah produk baik barang dan jasa yang dihasilkan oleh unit-unit produksi di dalam batas wilayah suatu negara (domestik) selama setahun. Perhitungan GDP juga akan memasukkan hasil produksi dari barang dan jasa yang dihasilkan oleh perusahaan atau orang asing jika beroperasi di wilayah negara yang bersangkutan.

\section{Tingkat Inflasi}

Pentingnya pengendalian inflasi didasarkan pada pertimbangan bahwa inflasi yang tinggi dan tidak stabil memberikan dampak negatif kepada kondisi sosial ekonomi masyarakat (www.BI.co.id). 


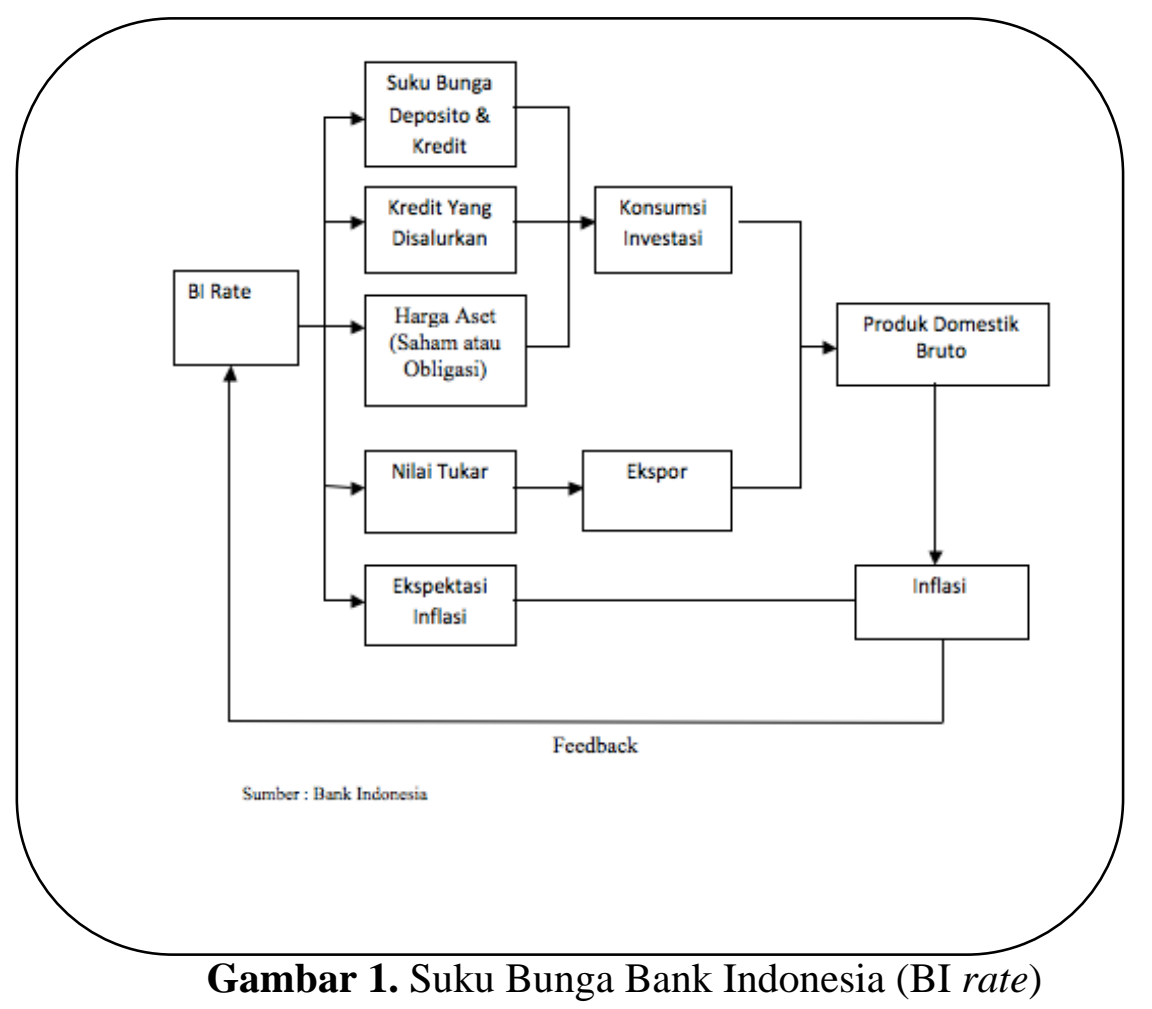

\section{Analisis Industri}

Analisis Strategi

Analisis strategi industri berkaitan dengan analisis industri perusahaan dan strateginya untuk menciptakan kelebihan yang kompetitif. Ratarata keuntungan sebuah perusahaan dipengaruhi oleh "five forces" (Palepu, 2009) :

\section{Rivalitas Diantara Perusahaan yang Sudah Ada Sebelumnya \\ 2. Ancaman Pendatang Baru \\ 3. Ancaman dari Produk Pengganti \\ 4. Daya tawar pembeli \\ 5. Daya tawar dari penjual}

\section{Analisis Strategi Bersaing (Competitive Strategy Analysis)}

Kemampuan perusahaan dalam menghasilkan pendapatan tidak hanya dipengaruhi oleh industri dimana perusahaan tersebut berada, akan tetapi juga dipengaruhi oleh kemampuan perusahaan dalam menetapkan dan menerapkan strategi-strategi bisnis. Ada 2 
pendekatan strategi bisnis yang memungkinkan perusahaan untuk membangun sustainable competitive advantage yaitu cost leadership dan differentiationstrategy (Palepu, 2009).

\section{Analisis Strategi Perusahaan (Corporate Strategy Analysis)}

Strategi yang telah diformulasikan dengan baik akan mampu mengurangi biaya atau menambah pendapatan setelah menjalankan beberapa bisnis dalam satu perusahaan dibanding dengan menjalankan beberapa bisnis secara terpisah dan saling melakukan transaksi di pasar (Palepu, 2009).

\section{Analisis Keuangan}

Analisis keuangan adalah suatu metode analisis yang digunakan untuk mengetahui kinerja perusahaan yang dipublikasikan dalam bentuk laporan keuangan.

\section{Analisis Rasio}

Salah satu tujuan dilakukannya analisis rasio adalah untuk melakukan perbandingan kinerja perusahaan dengan pesaingnya (competitor). Menurut Titman, S., Keown, J. A., Martin., D. J. (2011) ada 5 rasio yang biasa digunakan untuk mengevaluasi kinerja perusahaan, yaitu :

\section{a. Liquidity Ratios}

Menurut Kasmir (2008) rasio likuditas, "merupakan rasio yang digunakan untuk mengetahui kemampuan perusahaan dalam memenuhi kewajiban jangka pendek atau yang segera jatuh tempo".

- Current Ratio

$$
=\frac{\text { Current Asset }}{\text { Current Liabilities }}
$$

- $\quad$ Acid Test (Quick Ratio)

$$
=\frac{\text { Current Assets }- \text { Inventory }}{\text { Current Liabilities }}
$$

- Average Collection Period

$$
=\frac{\text { Accounts Receivable }}{\text { Annual Credit Sales/365 days }}
$$

- Accounts Receivable Turnover = Annual Credit Sales

Accounts Receivables

- Inventory Turnover

$$
=\underline{\text { Cost Of Good Sold }}
$$




\section{Inventories}

\section{b. Capital Structure Ratios}

Merupakan rasio yang digunakan untuk mengetahui bagaimana perusahaan membiayai assetnya, apakah dengan menggunakan debt atau dengan equity.

- Debt Ratio

$$
=\frac{\text { Total Debt }}{\text { Total Asset }}
$$

- Times Interest Earned

$$
=\frac{\text { Net Operating Income or EBIT }}{\text { Interest Expenses }}
$$

\section{c. Asset Management Efficiency Ratios}

Merupakan rasio yang digunakan untuk mengetahui seberapa efektif manajemen mengelola sumber daya yang dimiliki oleh perusahaan.

- Total Asset Turn Over = $\quad$ Sales

$$
\text { Total Asset }
$$

- $\quad$ Fixed Asset Turnover

$$
=\frac{\text { Sales }}{\text { Net Plan and Equipment }}
$$

\section{d. Profitability Ratio}

Rasio Profitabilitas merupakan rasio yang digunakan untuk mengukur kemampuan perusahaan untuk menghasilkan return atau pendapatan.

- Gross Profit Margin

$$
=\frac{\text { Gross Profit }}{\text { Sales }}
$$

- $\quad$ Net Profit Margin (NPM)

$$
=\frac{\text { Net Income }}{\text { Sales }}
$$

- $\quad$ Operating Profit Margin $(\mathrm{OPM})=\underline{\text { Net Operating Income or EBIT }}$ Sales

- Operating Return on Assets (OROA)= Net Operating Income /EBIT 
Total Assets

- Return on Equity

$=$ Net Income

Common Equity

e. Market Value Ratio

Merupakan rasio yang digunakan untuk mengetahui nilai saham perusahaan di pasar (stock market).

- $\quad$ Price Earnings Ratio

$$
=\frac{\text { Market Price Per Share }}{\text { Earnings per Share }}
$$

- $\quad$ Market To Book Ratio

$$
=\frac{\text { Market Price Per Share }}{\text { Book Value per Share }}
$$

\section{Valuasi}

Menurut Damodaran (2002), secara garis besar ada 3 pendekatan yang digunakan dalam melakukan valuasi, yaitu :

1) Relative Valuation

2) Contingent claim valuation

3) Discounted cash flow valuation

\section{Discounted Cash Flow Valuation}

Metode valuasi DCF memiliki tiga variasi perhitungan yang dapat digunakan untuk melakukan analisis valuasi saham yang sesuai dengan kebutuhan masing-masing analisis. Ketiga variasi tersebut adalah dividend discounted model, free cash flow to equity dan free cash flow to the firm

\section{Dividend Discount Model (DDM)}

Secara sederhana ketika seorang investor membeli sebuah saham, satu- satunya cash flow atau kas masuk yang diperoleh adalah berupa dividen (Damodaran, 2002). Sehingga berdasarkan pemikirian itu metode valuasi DDM, menilai intrinsik value saham sebuah perusahaan berdasarkan estimasi pendapatan yang dibagikan kepada shareholders yaitu berupa dividen dan men-discounting nilainya ke present value.

Metode valuasi DDM memiliki beberapa variasi perhitungan yang berhubungan dengan proyeksi pertumbuhan perusahaan.

\section{Free Cash Flow to Equity (FCFE)}


Free cash flow to equity adalah cash flow atau arus kas yang tersedia bagi pemegang saham setelah perusahaan memperhitungkan capital expenditure, working capital dan kewajiban hutang perusahaan (Damodaran, 2002).

\section{Free Cash Flow to Firm (FCFF)}

FCFF menghitung intrinsic value sebuah perusahaan dengan cara men-discountingfree cash flow to firm dengan weighted average cost of capital (WACC). Menurut Damodaran (2002), untuk menghitung FCFF dapat menggunakan rumus sebagai berikut :

$$
\begin{aligned}
& \text { Free Cash Flow to Firm }= \text { Free cash flow to equity }+ \text { Interest } \\
& \text { expense }(1-\text { Tax rate })+\text { Principal } \\
& \text { repayments }- \text { New debt issues }+ \\
& \text { Preferred dividends. }
\end{aligned}
$$

Atau perhitungan FCFF dapat dihitung dari earning before interest and taxes (EBIT) dengan menggunakan rumus sebagai berikut :

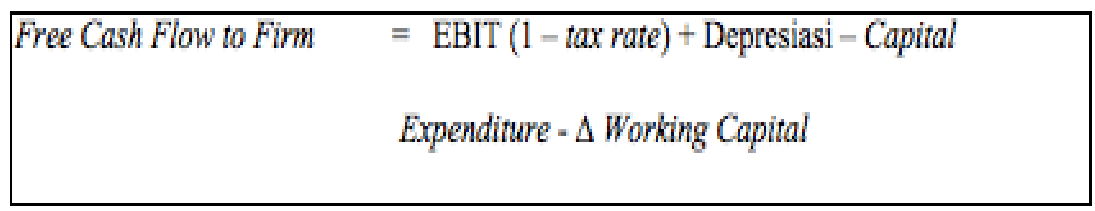

Metode perhitungan FCFF memiliki beberapa variasi perhitungan seperti constant growth (single stage), two stage dan three stage model (Damodaran, 2002).

\section{Estimasi Growth}

Menurut Damodaran (2002), ada 3 cara yang dapat digunakan oleh seorang analis untuk mengestimasikan nilai growth dari suatu perusahaan :

1) Melihat historical earning perusahaan dimasa lalu.

2) Dengan mempergunakan estimasi growth perusahaan yang dilakukan oleh analis.

3) Dengan melihat keadaan fundamental perusahaan.

\section{Discount Rate (Tingkat Suku Bunga Diskonto)}

Menurut Damodaran (2002) ada beberapa macam discount rate yang dapat dipakai, sesuai dengan metode valuasi yang digunakan oleh 
analis. Secara garis besar discount rate terbagi menjadi cost of equity, cost of debt dan cost of capital.

\section{Cost of Equity}

Cost of equity adalah tingkat pengembalian (require rate of return) yang diinginkan oleh investor ketika menginvestasikan dananya didalam perusahaan (Damodaran, 2002).

Expected Return $=$ riskless rate + beta (risk premium)

\section{Cost of Debt}

Cost of debt juga dapat diperoleh dari hasil proporsi atas tingkat bunga hutang terhadap hutang jangka pendek (short-term debt) dan hutang jangka panjang (long-term debt).

\section{Cost of Capital}

Cost of capital merupakan tingkat pengembalian yang diinginkan oleh penyedia dana perusahaan yaitu kombinasi antara equity, debt dan hybrid securities yang diproksikan dengan weighted average cost of capital (WACC).

\begin{tabular}{|c|c|}
\hline Cost of capital $=$ & $\begin{array}{l}k_{e}[E /(D+E+P S)]+k_{d}[D /(D+E+ \\
P S)]+k_{p s}[P S /(D+E+P S)]\end{array}$ \\
\hline
\end{tabular}

Keterangan :

$\mathrm{k}_{\mathrm{d}}=$ cost of debt, setelah pajak $(1-\mathrm{T})$

$\mathrm{k}_{\mathrm{ps}}=$ cost of preferred stockholder

$\mathrm{k}_{\mathrm{cs}}=$ cost of common stock

Perhitungan untuk cost of preferred stock $\left(\mathrm{k}_{\mathrm{ps}}\right)$ dapat menggunakan rumus sebagai berikut (Damodaran, 2002) :

$$
\mathrm{k}_{\mathrm{ps}}=\frac{\text { dividen per lembar saham preferen }}{\text { market price per share saham preferee }}
$$




\section{METODOLOGI PENELITIAN}

\section{Gambaran Umum Perusahaan}

Di Indonesia, PT Adaro merupakan perusahaan produsen tambang batu bara termal terbesar kedua yang mengelola dan memiliki tambang batubara tunggal yang paling besar di bumi bagian selatan. Pada awalnya PT Adaro dimiliki oleh perusahaan asing, yaitu : New Hope Corporation Australia (50\%), PT Asminco Bara Utama Indonesia (40\%), dan Mission Energy Amerika (10\%). Lalu mulai tahun 1989, perlahan lahan pemegang saham Indonesia mengambil alih kepemilikan dan manajemen PT Adaro.

PT Adaro adalah perusahaan yang beroperasi dibawah Perjanjian Karya Pengusahaan Pertambangan Batubara (PKP2B) generasi pertama bersama dengan 10 perusahaan batubara lainnya.

Produk batu bara yang diproduksi oleh PT Adaro memakai nama Envirocoal sebagai merek dagangnya. Hal ini disebabkan karena produk batu bara PT Adaro memiliki kandungan energi sedang dengan kadar abu (1\%-2\%), sulfur (0.1\%) serta nitrogen $(0.9 \%)$ yang sangat rendah.

\section{Initial Public Offering (IPO)}

Perusahaan secara resmi tercatat di Bursa Efek Indonesia (BEI) pada tanggal 16 Juli 2008 dan menunjuk PT Danatama Makmur sebagai underwriter.

Pada waktu IPO, perusahaan melakukan penawaran saham sebanyak 11.139.331.000 lembar saham atau 34\% dari modal saham yang ditempatkan dan disetor dengan harga saham perdana sebesar Rp.1.100.

\section{Struktur Organisasi dan Susunan Dewan Komisaris \& Direksi}

Adapun susunan dewan komisaris dan direksi dari PT Adaro Energy Tbk adalah sebagai berikut : 


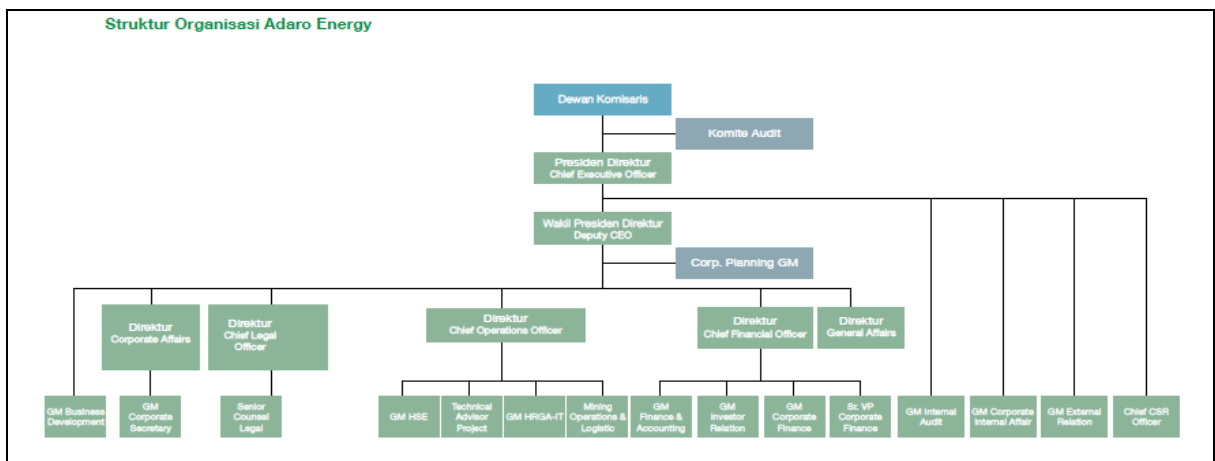

Sumber : Annual Report PT Adaro 2011

Gambar 2. Struktur Organisasi PT Adaro Energy Tbk

\section{Anak Perusahaan}

Berikut ini adalah anak perusahaan PT Adaro Energy Tbk yang masing-masing memiliki peranan yang sangat penting bagi berkembangan rantai pasokan batu bara perusahaan.

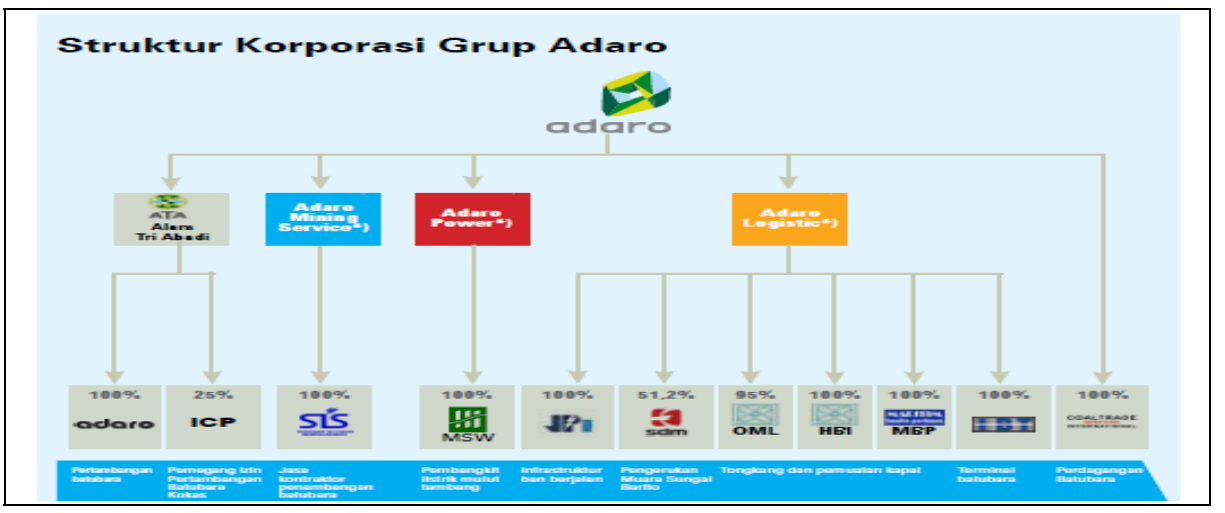

Sumber : Annual Report PT Adaro Energy Tbk 2011

Gambar 3. Anak Perusahaan PT Adaro 


\section{Kerangka Pikir}

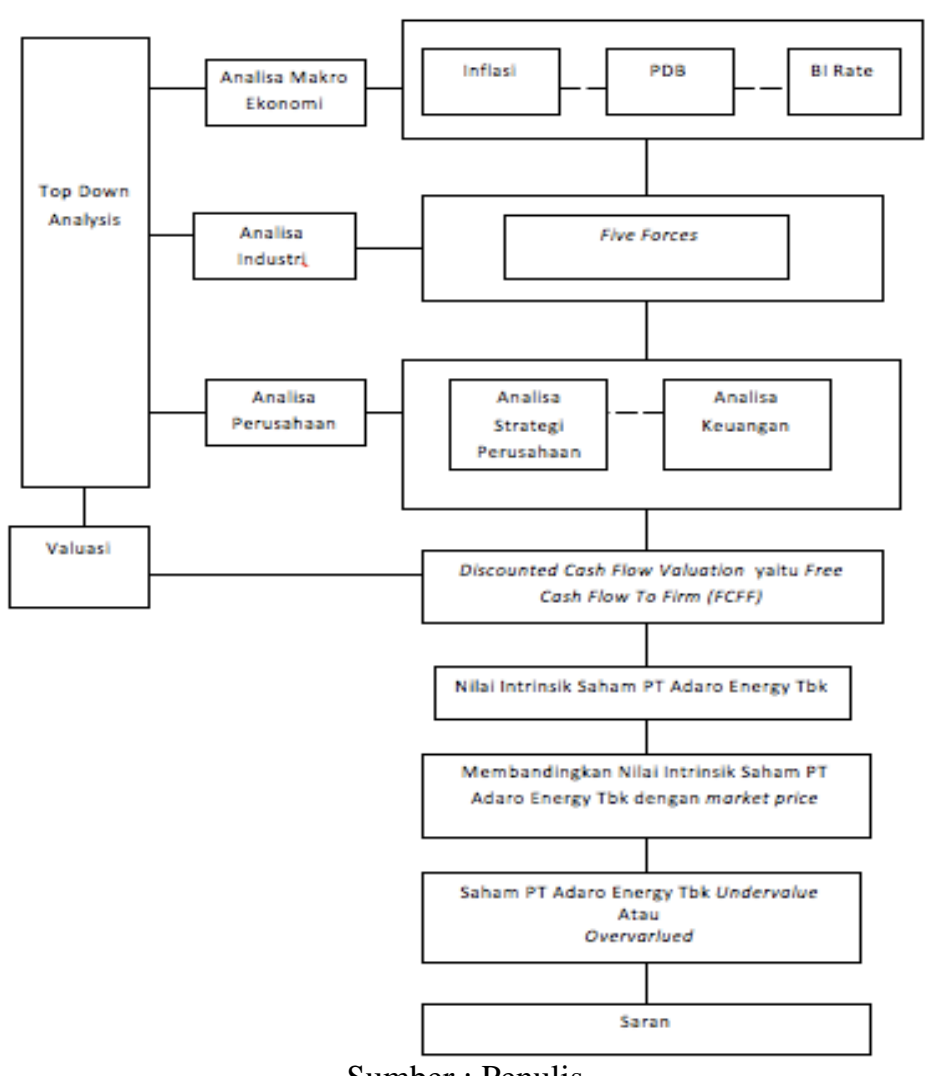

Sumber : Penulis

Gambar 4. Kerangka Pikiran

\section{Metode Pengumpulan Daata}

- Studi Kepustakaan.

\section{Sumber Data}

- Laporan keuangan PT Adaro Energi Tbk periode tahun 2007 2011 yang dapat diperoleh dari Bursa Efek Indonesia (BEI).

- Data harga saham perusahaan PT Adaro Energi Tbk dengan kode ADRO, yang dapat diperoleh di yahoo finance.

- Data variabel ekonomi makro Indonesia seperti BI Rate, tingkat inflasi, tingkat pertumbuhan Indonesia (GDP) yang dapat diperoleh dari internet atau media publikasi lainnya.

- Data Indeks Harga Saham Gabungan (IHSG) yang dapat diperoleh dari yahoo finance dan data surat hutang pemerintah 
(obligasi) yang dapat diperoleh dari Indonesia Bond Pricing Agency (IBPA).

\section{Metode Analisis}

Didalam penelitian ini, penulis akan menggunakan pendekatan metode free cash flow to firm (FCFF) untuk menghitung intrinsic value saham PT Adaro Energi Tbk, yang dapat dirumuskan sebagai berikut (Damodaran, 2002) :

$$
\text { Value of firm }=\sum_{t-1}^{t=n} \frac{\mathrm{CF} \text { to firm }}{(1+\mathrm{WACC})}
$$

Keterangan :

$$
\begin{array}{ll}
\mathrm{n} & =\text { Umur Aset } \\
\mathrm{CF} \text { to firmt } & =\text { Expected cash flow to firm pada periode } \mathrm{t} \\
\mathrm{WACC} & =\text { Weighted average cost of capital }
\end{array}
$$

\section{ANALISA DAN PEMBAHASAN}

\section{Industri Batu Bara}

\section{Gambaran Umum Batu Bara}

Berdasarkan proses geologi, batu bara dapat diklasifikasikan menjadi 6 kategori, yaitu (Jinsona, 2009) :

- Batu bara jenis peat atau biasa disebut batu bara gambut adalah batu bara muda (atau tahap awal).

- Batubara lignite merupakan batubara yang memiliki kualitas yang paling rendah dan biasa digunakan untuk sumber energi PLTU.

- Batubara sub-bituminous yang memiliki kualitas dan energi diantara batu bara lignite dan peat. Biasa digunakan untuk bahan bakar PLTU dan industri kimia.

- Batubara anthracite yang merupakan jenis batu bara yang memiliki peringkat yang paling tinggi

- Batu bara jenis graphiteyang biasa digunakan sebagai bahan campuran pembuat pensil atau pelumas

\section{Gambaran Industri Batu Bara}

Menurut data yang dipublikasikan oleh World Coal Assosiation (2010), Indonesia masuk kedalam 10 negara produsen batu bara terbesar dunia, yaitu menduduki peringkat ke 7 (China, USA, India, 
Australia, Afrika, Russia, Indonesia, Kazakhtan, Polandia dan Columbia). Hampir sebagian besar batu bara Indonesia diproduksi di Kalimantan dan Sumatra, selain itu batu bara Indonesia juga dihasilkan di Jawa, Sulawesi dan daerah lainnya.

Sebagai produsen batubara, Indonesia merupakan negara peringkat ke 7 dunia, namun dengan semakin meningkatnya ekspor batu bara thermal, maka pada tahun 2006 Indonesia menduduki peringkat ke-2 sebagai negara pengekspor batu bara terbesar di dunia setelah Australia. Bahkan sekarang Indonesia merupakan negara peringkat 1 di dunia sebagai pengekspor batu bara thermal.

Cina dan India adalah dua negara yang paling banyak menggunakan batu bara sebagai sumber energi di dunia, hampir setengah dari total produksi batubara global digunakan oleh kedua negara ini dan diperkirakan akan menyerap 73\% dari total produksi dunia pada tahun 2030. Di Cina hampir 80\% sedangkan di India hampir 70\% sumber energi listrik menggunakan batu bara (Mardiani, D., 2012).

Untuk didalam negeri, hampir sebagian besar batu bara digunakan untuk pembangkit listrik atau PLTU, yaitu sekitar 70\% dari total konsumsi batu bara domestik, 17\% oleh industri semen, 10\% oleh industri kertas \& tekstil dan sisanya digunakan oleh industri lainnya.

Dimasa yang akan datang, pemerintah akan lebih mendorong penggunaan batu dara didalam negeri. Pemerintah melalui Peraturan Presiden No 5 tahun 2006 mengenai Kebijakan Energi Nasional berusaha untuk mengurangi ketergantungan terhadap satu jenis energi saja seperti minyak bumi dan mulai memanfaatkan sumber energi alternatif lainnya seperti batu bara.

\section{Perkembangan Harga Batu Bara}

Batu bara adalah komoditas yang harganya dipengaruhi oleh supply dan demand dari pasar global batu bara di dunia. Beberapa hal yang mempengaruhi harga batu bara adalah: tingkat produksi dari produsen batu bara, distribusi (supply chain) batu baru, keadaan perekonomian dunia, dan tingkat konsumsi atau penggunaan batu bara dari konsumen.

Krisis ekonomi global yang masih berkelanjutan telah mempengaruhi harga batu bara jenis thermal di Pelabuhan Newcastle yang berada di 
Australia, yang merupakan harga acuan untuk batu bara jenis thermal di kawasan Asia.

\section{Analisis Ekonomi Makro}

Dana Moneter Internasional (IMF) memperkirakan pertumbuhan ekonomi yang lebih rendah dari yang diharapkan akan terjadi di negara-negara utama yang baru bangkit dari krisis ekonomi. Ekonomi global akan tumbuh 3,5\% tahun 2012 dan 3,9\% pada tahun 2013, sedikit lebih rendah dari perkiraan sebelumnya karena tengah melemahnya investasi, bursa kerja, dan manufaktur di Eropa, AS, Brazil, India, dan China. Namun, situasi ekonomi bisa lebih buruk jika upaya memperbaiki situasi di Eropa terhambat, atau jika kemacetan politik di Washington menjurus pada pemotongan belanja dan kenaikan pajak drastis (Pikiran Rakyat Online, 2012). Rapuhnya perekonomian global terlihat dengan aksi pemotongan suku bunga acuan di China dan Eropa kemarin. Berdasarkan data IMF negaranegara berkembang utama seperti Brazil, China, India, dan Rusia akan memenuhi 20\% perekonomian dunia pada tahun ini (Newswire, 2012).

Perlambatan perekonomian global ini merupakan dampak atas krisis utang zona euro ataupun gejolak harga minyak karena kondisi geopolitik. Para pemimpin Eropa telah beruapaya memperbaiki aturan fiscal, pembelian Sentral Eropa membanjiri pasar dengan uang untuk mengembalikan imbal hasil obligasi di Italia, Spanyol, dan Yunani. Hal tersebut diperkuat oleh dana bailout yang diperbesar oleh para pemimpin zona euro. Bank-bank Eropa juga akan mengurangi belanja mereka sebesar USD 2,6 triliun selama dua tahun ke depan dan sekitar $1 \%$ dari pertumbuhan tahun ini. Karenanya, zona euro kemungkinan akan mengalami resesi ringan tahun ini sebelum berangsur membaiknya perekonomian global pada tahun 2013. Di sisi lain, kondisi perekonomian AS juga masih rentan di tengah risiko fiskal ke depan yang masih dalam proses sebelum berangsur membaiknya perekonomian global pada tahun 2013. Di sisi lain, kondisi perekonomian AS juga masih rentan di tengah risiko fiskal ke depan yang masih dalam proses penyelesaian (Martin Bagya Kertiyasa, 2012).

Pelemahan perekonomian global juga berdampak pada melambatnya ekspor ditengah masih tingginya impor, karena kuatnya permintaan domestik. Perekonomian global melemah dan diliputi ketidakpastian 
yang cukup besar. Penyelesaian krisis di Eropa diperkirakan masih memerlukan waktu yang panjang, meskipun terdapat sejumlah kemajuan dengan hasil European Union Summit beberapa waktu yang lalu. Harga komoditas global, termasuk harga minyak, terus menurun seiring dengan permintaan dunia yang melemah. Hal itu juga diikuti dengan tekanan inflasi global yang terus menurun. (Koran Jakarta, 2012).

Stabilitas ekonomi makro Indonesia pada triwulan I-2012 tetap terjaga sesuai dengan yang diharapkan. Kondisi perekonomian dan keuangan global yang masih mengalami perlambatan seiring berlarutnya krisis di Eropa tidak menimbulkan dampak signifikan bagi perekonomian Indonesia. Berbagai indikator makro, moneter, perbankan dan sistem pembayaran menunjukkan kondisi yang positif.

Pertumbuhan ekonomi Indonesia pada triwulan I-2012, meskipun dibayangi kemungkinan adanya kebijakan BBM pemerintah, diperkirakan masih tetap tinggi.

Kinerja Neraca Pembayaran Indonesia (NPI) selama triwulan I-2012 mengalami penurunan karena menurunnya kinerja neraca transaksi berjalan akibat ekspor yang melambat dan impor yang meningkat. Sementara transaksi modal dan finansial (TMF) diperkirakan masih mengalami surplus yang cukup besar ditopang oleh aliran investasi langsung dan portofolio.

\section{Produk Domestik Bruto}

Meskipun berada ditengah perlambatan perekonomian global, perekonomian Indonesia diperkirakan akan terus bertumbuh pada kisaran 6,1\%-6,5\% pada tahun 2012 setelah Bank Indonesia merevisi target sebelumnya sebesar 6,3\%-6,7\% karena terjadinya penurunan kinerja ekspor dan pertumbuhan ekonomi triwulan III. Peningkatan perekonomian ini diprediksi akan mencapai 6,6\%-7,4\% hingga tahun 2016 bila konsumsi rumah tangga tetap tinggi, iklim investasi yang semakin kondusif, peringkat Moody's dengan outlook stabil dan investment grade oleh Fitch bagi Indonesia dapat dipertahankan, meskipun kegiatan ekspor mengalami penurunan. Namun, bila krisis ekonomi tidak menemukan jalan penyelesaian yang cepat, maka pertumbuhan Indonesia akan mencapai persentase terburuk berkisar $3,8 \%-4 \%$. 


\section{Tingkat Inflasi}

Tingkat inflasi Indonesia sempat naik tajam ke angka 12,14\% pada masa krisis Eropa 2008. Pada tahun 2009 menuju 2010, tingkat inflasi tersebut perlahan-lahan menurun seiring berakhirnya krisis Eropa. Namun, inflasi kembali meningkat saat terjadi krisis ekonomi dunia tahun 2011. Peningkatan ini memang tidak setajam pada masa sebelumnya karena Indonesia mampu mengendalikan inflasi berkat harga komoditas global yang terkoreksi cukup tajam, nilai tukar mata uang yang cukup stabil, dan proyeksi yang terus membaik hingga dapat menekan laju inflasi di tahun 2011. Pertumbuhan ekonomi Indonesia pada triwulan I-2012, meskipun dibayangi kemungkinan adanya kebijakan BBM pemerintah, diperkirakan masih tetap tinggi. Ditopang oleh inflasi yang terkendali, perekonomian triwulan I-2012 diperkirakan tumbuh sebesar 6,5\%. Sumber utama pertumbuhan ekonomi berasal dari konsumsi rumah tangga yang masih kuat sejalan dengan optimise konsumen yang tinggi.

Tekanan inflasi IHK pada triwulan I-2012 terutama berasal dari kelompok volatile food. Inflasi kelompok volatile food pada triwulan laporan tercatat sebesar 4,45\%, melonjak dari triwulan sebelumnya deflasi 3,37\%. Perkembangan inflasi volatile food triwulan laporan ini cukup berbeda dengan pola musimannya, dimana pada triwulan pertama tahun calendar pada umumnya mencatat inflasi yang rendah. Risiko inflasi dapat dipicu oleh ketidakpastian rencana penyesuaian harga BBM subsidi. Upaya-upaya yang terus dilakukan oleh pemerintah untuk mengarahkan inflasi 2012 dan 2013 menuju sasaran inflasi pada kisaran 4,5\% - 1\%.

\section{Suku Bunga Bank Indonesia (BI RATE)}

Pada bulan Oktober 2011 hingga akhir tahun 2011, BI rate kembali diturunkan menjadi 6\% secara bertahap seiring masih terbatasnya permintaan domestik dan terus menurunnya ekpektansi inflasi. Pada Maret 2012, Bank Indonesia mempertahankan BI rate sebesar 5,75\%. Tingkat BI rate tersebut dinilai masih konsisten dengan tekanan inflasi dari sisi fundamental ke depan yang diperkirakan masih relative terkendali. Meskipun demikian, Bank Indonesia tetap mewaspadai risiko peningkatan tekanan inflasi secara temporer ke depan dari kemungkinan adanya kebijakan terkait BBM yang ditempuh pemerintah. 


\section{Analisis Industri}

\section{Analisis FIVE FORCES}

\section{Rivalitas Diantara Perusahaan}

Industri batu bara di Indonesia didominasi oleh 3 perusahaan besar yaitu PT Bumi Resources (30, 30\%) , PT Adaro Energy (20, 20 \%) dan PT Kideco Jaya Agung (10,60\%). Sedangkan sisanya memiliki pangsa pasar yang tidak lebih dari 7\%.

\section{Ancaman Pendatang Baru}

Industri batubara Indonesia berkembang dengan sangat baik dan memungkinkan dapat menarik perhatian dari pendatang baru untuk masuk ke dalam industri tersebut.Industri batubara barrier to entry relatif besar. Sehingga dapat disimpulkan jika ancaman pendatang baru adalah lemah.

\section{Ancaman dari Produk Pengganti}

Dengan isu kenaikan harga bahan bakar minyak yang berkembang di dunia, batubara akan menjadi pilihan yang cukup baik bagi beberapa pihak untuk menggantikan fungsi dari bahan bakar minyak.

\section{Daya Tawar Pembeli}

Cina dan India merupakan dua negara konsumenterbesar batu bara dunia dan merupakan 2 negara utama pembeli batu bara dunia. Sehingga dapat dikatakan bahwa kedua negara tersebut dapat mempengaruhi untuk menaikan atau menurunkan harga batu bara karena memiliki posisi tawar yang kuat. Perlambatan ekonomi yang terjadi di Cina dan India yang disebabkan oleh krisis ekonomi global, telah mempengaruhi harga batu bara dunia. Berdasarkan pemaparan diatas dapat dikatakn jika daya tawar pembeli cukup tinggi.

\section{Daya Tawar Penjual}

Penjual atau supplier dalam industri batu bara memang cukup banyak, akan tetapi untuk supplier yang memiliki cadangan batu bara yang besar, jumlah produksi yang mampu memenuhi kebutuhan konsumen dan memiliki pangsa pasar yang cukup besar hanya sedikit. Sehingga dapat disimpulkan jika daya tawar penjual relative sedang. 


\section{Analisis Strategi Bersaing (Competitive Strategy Analysis)}

Tingkat profitabilitas perusahaan akan dipengaruhi oleh struktur industri dan pilihan strategi untuk memposisikan diri di industri. Berikut adalah beberapa pilihan strategi yang digunakan PT Adaro dalam memposisikan dirinya :

- Low cost producer (produsen berbiaya rendah)

- Large operation (operasi besar)

- Unique coal (Keunikan batubara)

- Tenaga kerja dengan keahlian yang terampil disertai pengalaman bertahun-tahun

- PT Adaro Energy Tbk dan anak perusahaannya menjual envirocoal kepada para konsumen yang beragam dari 41 perusahaan di 17 negara di seluruh dunia.

- Infrastruktur PT Adaro Energy Tbk memberikan perusahaan kemampuan untuk meningkatkan produksi dengan cepat.

- PT Adaro Energy Tbk memiliki rencana agar rantai pasokan batubara setiap anak perusahaannya terintegrasi.

- Unit strategi bisnis PT Adaro Energy Tbk berpengalaman dalam sektor pertambangan, perdagangan, jasa kontraktor pertambangan dan infrastruktur, dan logistik.

- Aset dengan kualitas yang tinggi serta 3,5 miliar ton cadangan dan sumber daya batubara.

\section{Analisis Strategi Perusahaan (Corporate Strategy Analysis)}

- PT Adaro Energy Tbk memiliki target untuk dapat berproduksi hingga mencapai 80 juta ton per tahun dalam jangka menengah.

- Merencanakan untuk meningkatkan produksi batubara menjadi tiga atau empat juta ton per tahun sampai tahun 2014, dan kemudian ditingkatkan lagi sampai sepuluh juta ton per tahun dalam kurun waktu lima tahun sejak operasi dimulai.

\section{Analisis Keuangan (Financial Analysis) Analisis Rasio}

Analisa rasio dilakukan untuk mengetahui kinerja PT Adaro jika dibandingkan dengan industrinya. Berikut ini adalah chart perbandingan rasio PT Adaro Energy Tbk dengan industrinya : 
a. Liquidity Ratios

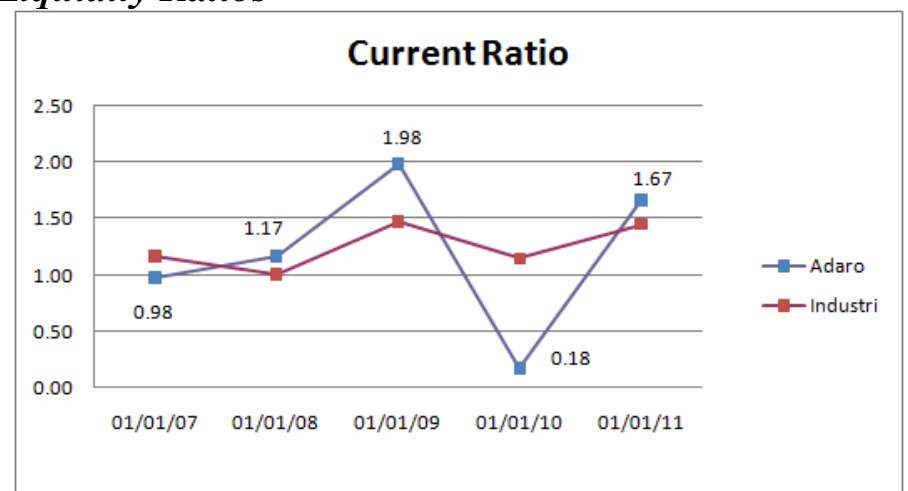

Sumber : Data Diolah

Gambar 5. Current Ratio

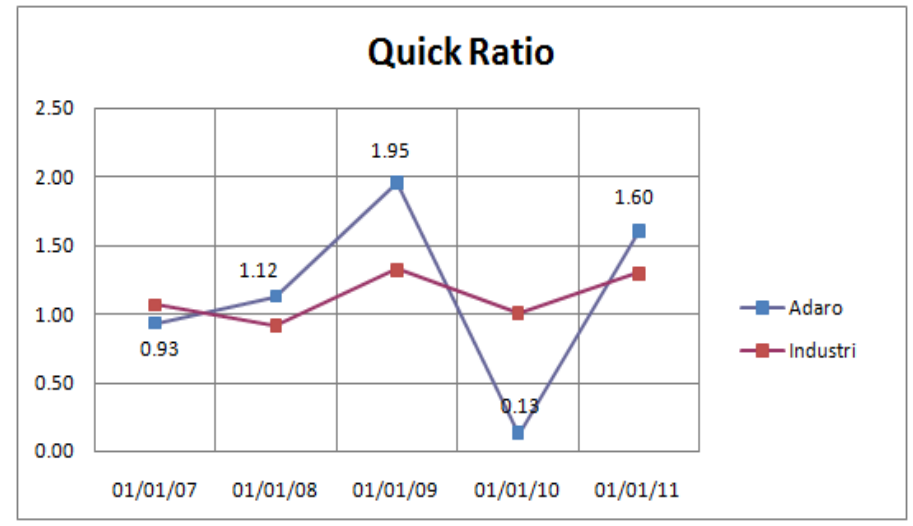

Sumber : Data Diolah

Gambar 6. Quick Ratio

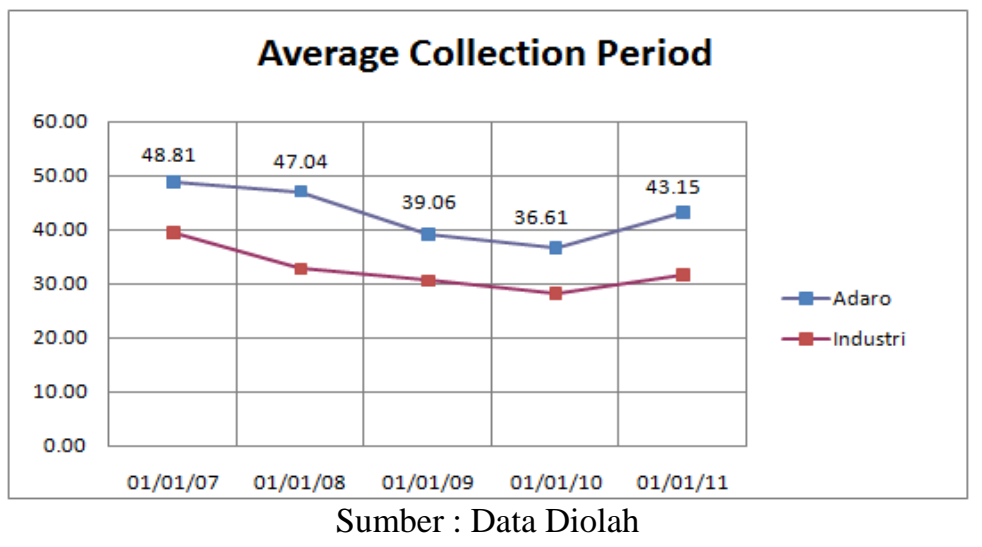

Gambar 7. Average Collection Period 


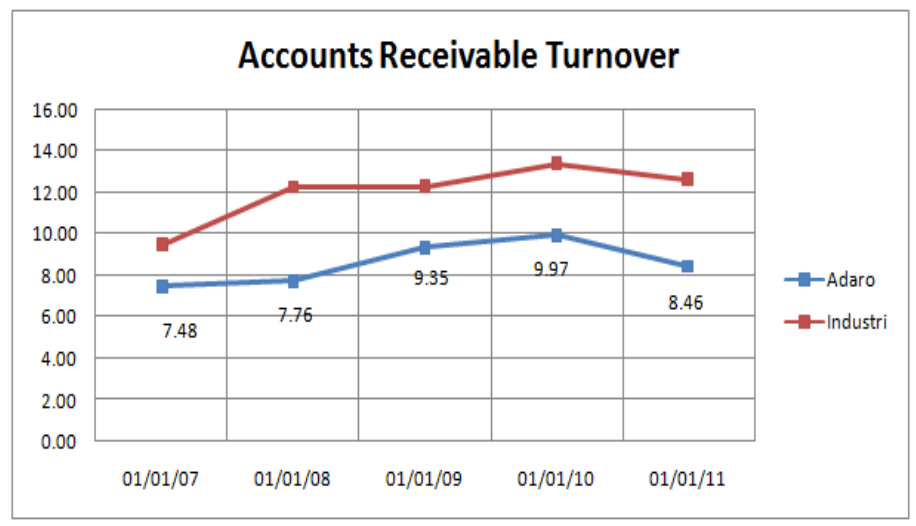

Sumber : Data Diolah

Gambar 8. Accounts Reveivable Turnover

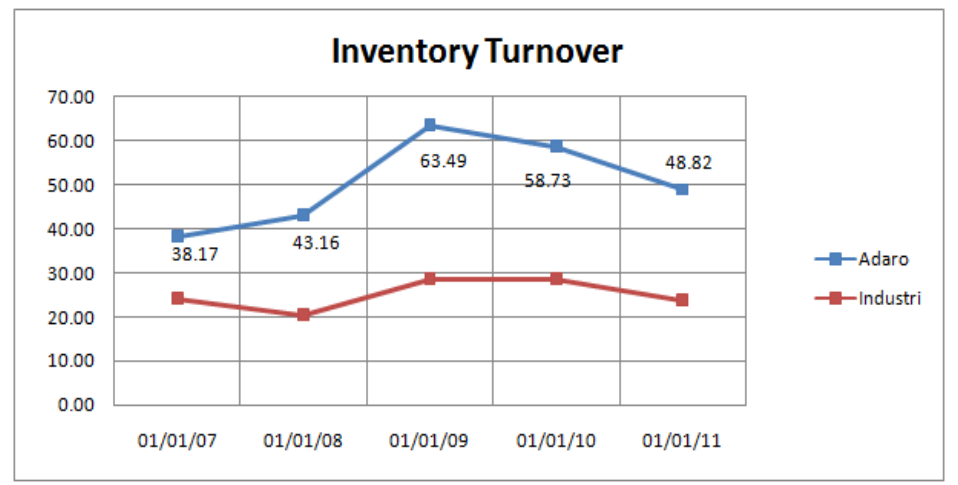

Sumber : Data Diolah

Gambar 9. Inventory Turnover

\section{c. Capital Structure Ratios}

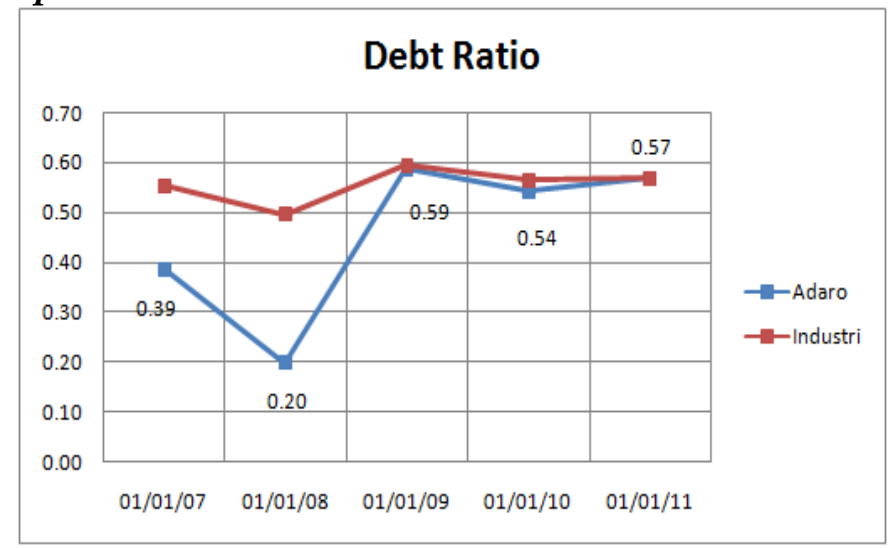

Sumber : Data Diolah

Gambar 10. Debt Ratio 


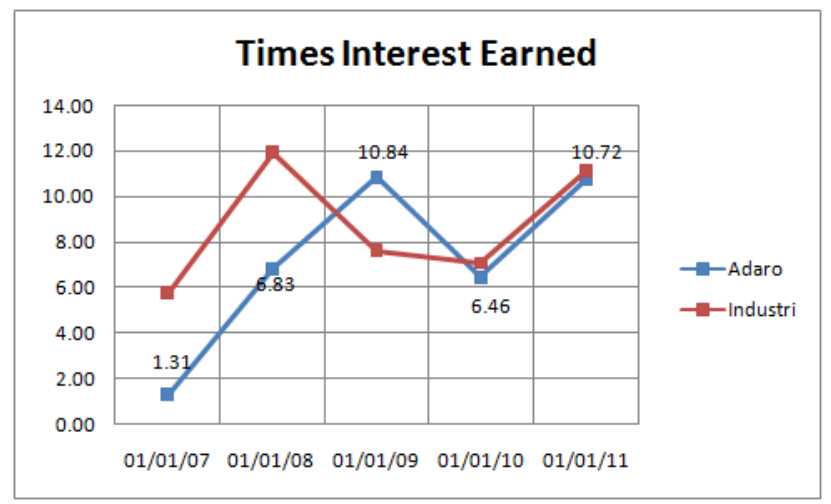

Sumber : Data Diolah

Gambar 11. Times Interest Earned

\section{d. Asset Management Efficiency Ratios}

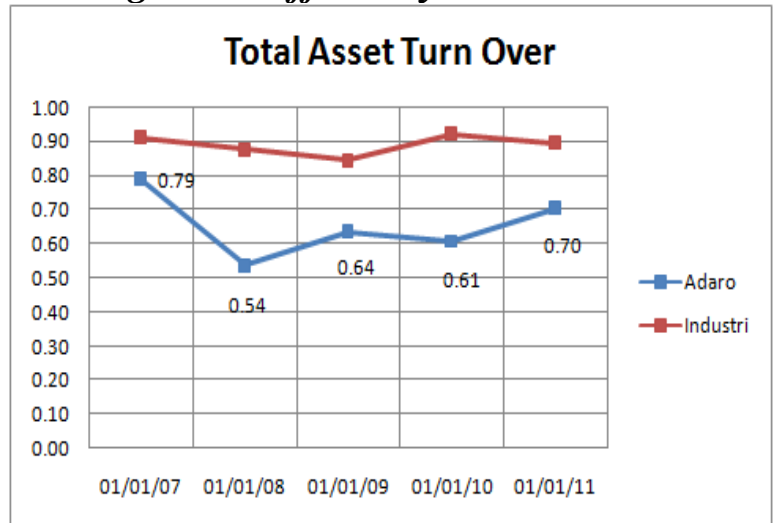

Sumber : Data Diolah

Gambar 12. Total Asset Turn Over

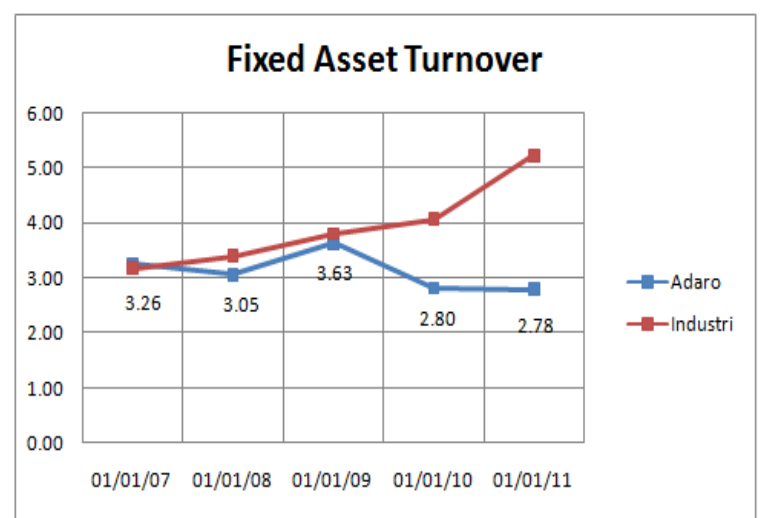

Sumber : Data Diolah

Gambar 13. Fixed Asset Turnover 


\section{d. Profitability Ratio}

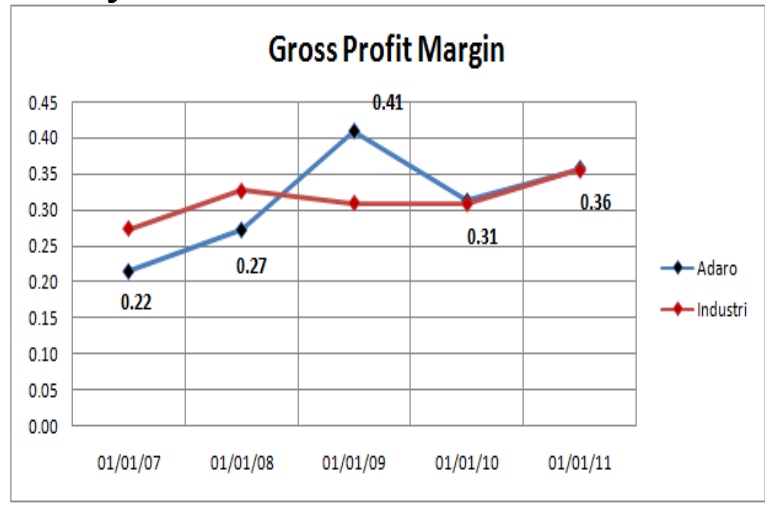

Sumber : Data Diolah

Gambar 14. Gross Profit Margin

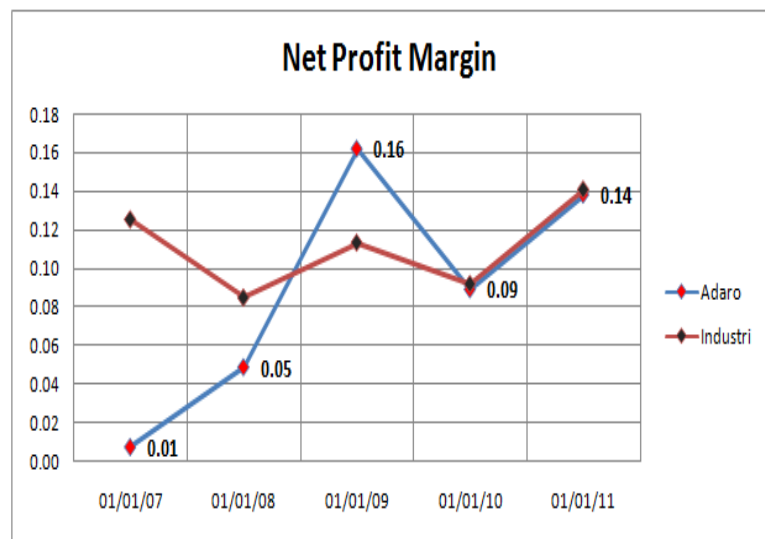

Sumber : Data Diolah

Gambar 15. Net Profit Margin

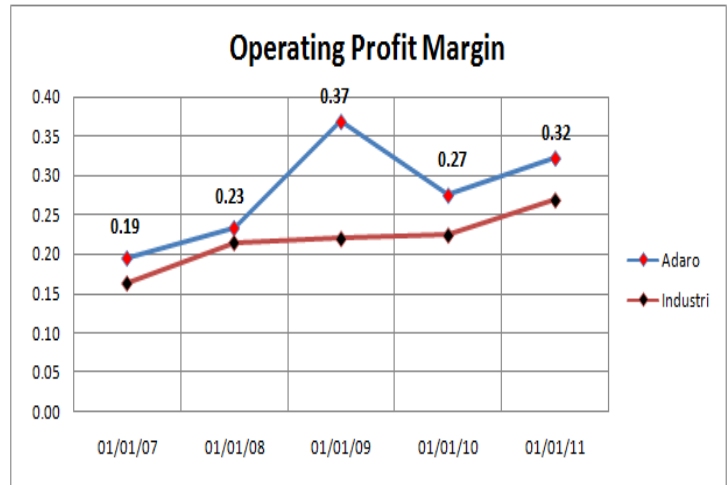

Sumber : Data Diolah

Gambar 16. Operating Profit Margin 


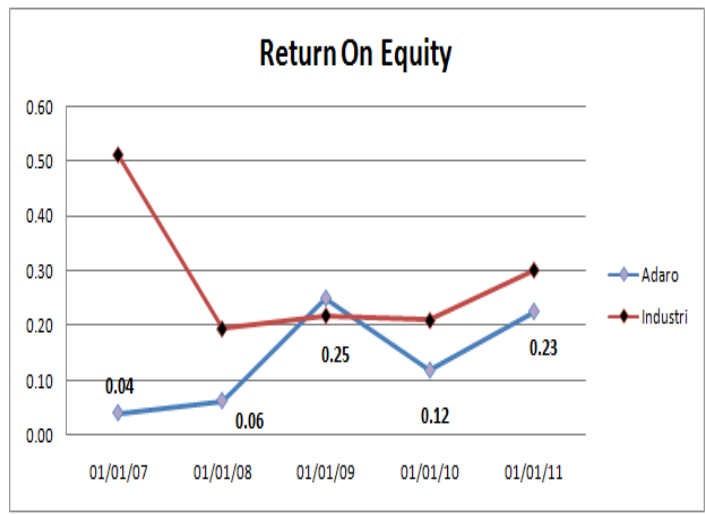

Sumber : Data Diolah

Gambar 17. Return On Equity

\section{e. Market Value Ratio}

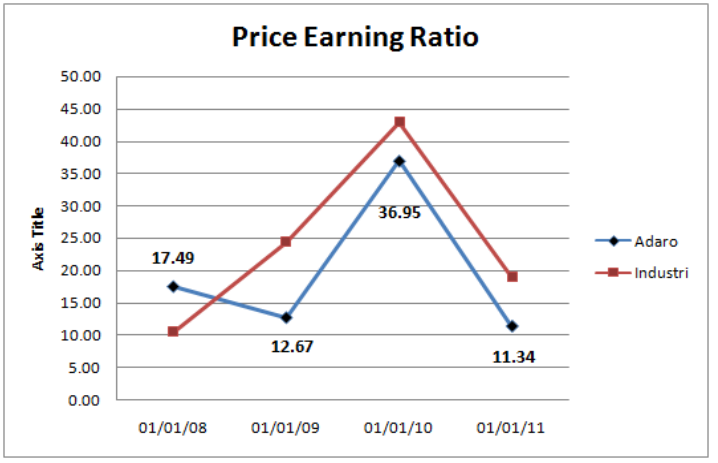

Sumber : Data Diolah

Gambar 18. Price Earning Ratio

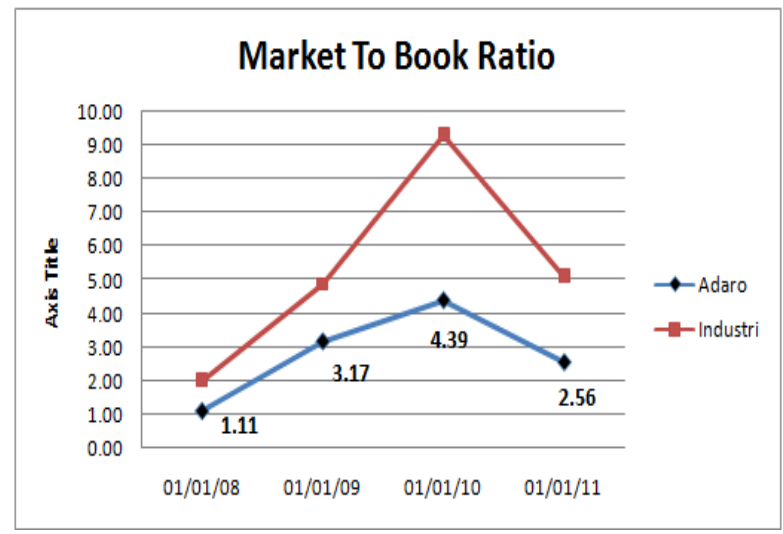

Sumber : Data Diolah

Gambar 19. Market To Book Ratio 


\section{Discount Rate (Tingkat Suku Bunga Diskonto)}

Metode yang digunakan untuk valuasi adalah Free Cash Flow to Firm two stage yaitu tahap high growth dan stable growth. Untuk tahap high growth akan digunakan WACC (Weighted Average Cost of Capital) yang meliputi cost of equity dan cost of debt. Sementara untuk tahap stable growth akan diasumsikan menggunakan nilai proyeksi GDP Indonesia tahun 2011 sebesar 6.46\%.

Tabel 1. Cost Of Equity

\begin{tabular}{l|r|}
\hline Risk Free Rate & $6.04 \%$ \\
\hline Risk Premium & $9.60 \%$ \\
\hline Beta & 1.24 \\
\hline Maka cost of equity & $17.94 \%$ \\
\hline \multicolumn{2}{|c|}{ Sumber : Data Diolah }
\end{tabular}

Tabel 2. Cost Of Debt

\begin{tabular}{|c|l|c|c|c|c|c|}
\hline No & \multicolumn{1}{|c|}{ Hutang } & Jumlah Hutang & Rate & Jumlah Hutang (Rp) & Weight (\%) & Biaya Hutang \\
\hline & USD (Kurs Rp 9.068) & & & & & \\
\hline 1 & Syndicated Loan (DBS Bank Ltd) & 387,500 & $5.03 \%$ & $3,513,850,000$ & $18.73 \%$ & $0.94 \%$ \\
\hline 2 & PT Bank OCBC NISP Tbk & 11,499 & $4.08 \%$ & $104,272,932$ & $0.56 \%$ & $0.02 \%$ \\
\hline 3 & Syndicated Bank Loan & 300,000 & $5.08 \%$ & $2,720,400,000$ & $14.50 \%$ & $0.74 \%$ \\
\hline 4 & Kredit Amortising Revolving & 420,000 & $5.43 \%$ & $3,808,560,000$ & $20.30 \%$ & $1.10 \%$ \\
\hline 5 & Syndicated Bank Loan & 150,000 & $5.63 \%$ & $1,360,200,000$ & $7.25 \%$ & $0.41 \%$ \\
\hline 6 & Senior Notes & 800,000 & $7.625 \%$ & $7,254,400,000$ & $38.67 \%$ & $2.95 \%$ \\
\hline & & & & $18,761,682,932$ & $100 \%$ & $6.16 \%$ \\
\hline
\end{tabular}

Sumber : Data Diolah

Tabel 3. Cost Of Capital

\begin{tabular}{|l|r|}
\hline Cost Of Equity & $17.90 \%$ \\
\hline Cost Of Debt & $6.16 \%$ \\
\hline Tax & $45 \%$ \\
\hline Debt Ratio & $44.20 \%$ \\
\hline Equity Ratio & $55.80 \%$ \\
\hline WACC & $11.49 \%$ \\
\hline
\end{tabular}

Sumber : Data Diolah 


\section{Valuasi \\ Discounted Cash Flow Valuation \\ Free Cash Flow to Firm (FCFF)}

Tabel 4. Free Cash Flow To Firm (FCFF)

\begin{tabular}{|c|c|c|c|c|c|c|}
\hline & $2012 \mathrm{~F}$ & $2013 \mathrm{~F}$ & $2014 \mathrm{~F}$ & $2015 \mathrm{~F}$ & $2016 \mathrm{~F}$ & TV \\
\hline DCF & 1 & 2 & 3 & 4 & 5 & \\
\hline EBIT & $9,086,419$ & $9,771,207$ & $10,151,024$ & $10,621,152$ & $11,845,894$ & \\
\hline Tax Rate & $45.00 \%$ & $45.00 \%$ & $45.00 \%$ & $45.00 \%$ & $45.00 \%$ & \\
\hline NOPLAT & $4,997,530$ & $5,374,164$ & $5,583,063$ & $5,841,634$ & $6,515,241$ & \\
\hline Depreciation & $(577,664)$ & $(600,770)$ & $(622,909)$ & $(637,167)$ & $(653,752)$ & \\
\hline Chnages in working capital & 885,683 & 79,534 & 63,764 & 79,550 & 149,289 & \\
\hline Capex & $(1,343,836)$ & $(1,320,730)$ & $(1,024,091)$ & $(1,076,526)$ & $(1,131,126)$ & \\
\hline Free Cash Flow To Firm (FCFF) & $3,961,714$ & $3,532,197$ & $3,999,827$ & $4,207,491$ & $4,879,652$ & $98,976,857$ \\
\hline
\end{tabular}

\section{Nilai Perusahaan (Value of the Firm)}

Tabel 5. Nilai Perusahaan (Value Of The Firm)

\begin{tabular}{l|r|r|r|r|r|c|} 
(In Rp '000.000') & \multicolumn{1}{c|}{ 2012F } & \multicolumn{1}{c|}{$2013 \mathrm{~F}$} & \multicolumn{1}{c|}{ 2014F } & \multicolumn{1}{c|}{ 2015F } & \multicolumn{1}{c|}{ 2016F } & \multicolumn{1}{c|}{ TV } \\
\hline Free Cash Flow To Firm (FCFF) & $3,961,714$ & $3,532,197$ & $3,999,827$ & $4,207,491$ & $4,879,652$ & $98,976,857$ \\
Discount factor & 1.11 & 1.24 & 1.39 & 1.54 & 1.72 & \\
PV & $3,553,482$ & $2,841,757$ & $2,886,385$ & $2,723,374$ & $2,832,982$ & $57,463,048$ \\
Enterprise value & $72,301,027$ & & & & & \\
Net debt & $12,629,056$ & & & & & \\
Equity value & $59,671,971$ & & & & & \\
\hline
\end{tabular}

Sumber : Data Diolah

\section{Nilai Ekuitas (Value of Equity dan Nilai Saham/Lembar)}

Tabel 6. Value Of Equity dan Nilai Saham/lembar

\begin{tabular}{|l|r|}
\hline Enterprise value & $72,301,027$ \\
\hline Net debt & $12,629,056$ \\
\hline Equity value & $59,671,971$ \\
\hline Outstanding shares & 1,866 \\
\hline Equity value/share & 1,570 \\
\hline Market Price (6 Juli 2012) &
\end{tabular}

Sumber : data diolah 


\section{KESIMPULAN DAN SARAN}

\section{Kesimpulan}

Berdasarkan analisis dan pembahasan pada bab sebelumnya, maka dapat diperoleh kesimpulan sebagai berikut :

1. Nilai intrinsik saham PT Adaro Energy Tbk pada tanggal 6 Juli 2012 dengan menggunakan metode Free Cash Flow To Firm (FCFF) adalah sebesar Rp. 1.866. Sedangkan harga saham (market value) pada tanggal 6 Juli 2012 adalah sebesar Rp.1,570. Jika dibandingkan antara nilai intrinsik dan market value, dapat dikatakan bahwa saham PT Adaro masih undervalued (nilai saham lebih rendah jika dibandingkan dengan nilai intrinsiknya).

2. Dari analisis rasio dapat disimpulkan bahwa :

- Dari sisi likuiditas yang dilihat dari current ratio dan acid ratio dapat dikatakan bahwa PT Adaro cukup likuid untuk membayar kewajiban jangka pendeknya dan rasio perusahaan berada diatas rata-rata industrinya. Sedangkan untukaccounts receivable turnoverdanaverage collection period berada dibawah rata-rata industri yang berarti bahwa pihak manajemen perusahaan kurang baik dalam mengelola piutang atau kurang berhasil dalam melakukan penagihan piutang kepada konsumennya.

- Dari sisi capital structure ratios, debtratio PT Adaro mengalami peningkatan yang disebabkan perusahaan membutuhkan dana tambahan untuk membiayai ekspansinya

- Dari sisi asset management efficiency ratios, baik total asset turnovermaupun fixed asset turnover ratio PT Adaro berada dibawah rata-rata industrinya. Hal ini berarti bahwa perusahaan belum mampu untuk memaksimalkan kapasitas aktiva yang dimilikinya jika dibandingkan dengan perusahaan lain yang sejenis untuk menghasilkan penjualan. Sehingga diharapkan dimasa depan perusahaan dapat meningkatkan lagi penjualannya atau mengurangi sebagian asset nya yang kurang produktif.

- Dari sisi profitability ratio, pendapatan PT Adaro cenderung mengelami peningkatan jika dibandingkan dengan tahun sebelumnya, namun berada dibawah rata-rata industrinya. Peningkatan pendapatan ini adalah akibat meningkatnya 
penjualan batu bara perusahaan yang didukung oleh faktor cuaca dan adanya peralatan tambang baru.

- Dari sisi market value ratio, baik price earning ratio maupun market to book ratio perusahaan berada dibawah rata-rata industrinya. Sehingga dapat dikatakan jika saham PT Adaro underprice atau lebih murah jika dibandingkan dengan harga saham industrinya.

3. Berdasarkan analisis five forces dapat dikatakan jika industri batu bara merupakan industri yang cukup menarik dengan rivalitas diantara perusahaan yang relative sedang, ancaman pendatang baru yang kecil, ancaman dari produk pengganti yang cukup besar, daya tawar pembeli yang relative tinggi dan daya tawar penjual yang relatif sedang.

\section{Keterbatasan Penelitian}

Penelitian ini masih memiliki keterbatasan. Oleh karena itu, bagi pihak akademisi maupun praktisi yang akan menggunakan hasil penelitian ini sebagai dasar untuk penelitian selanjutnya perlu memahami bahwa hasil yang diperoleh menggunakan data historis dan data pendukung sekunder lainnya tanpa memperoleh informasi langsung (wawancara) dari perusahaan terkait dengan rencana perusahaan ke depan.

\section{Saran}

1. Dengan keadaan ekonomi global yang tidak sehat seperti saat ini, PT Adaro Energy Tbk dapat menambah jumlah sahamnya yang beredar di publik sehingga bisa menambah kepercayaan investor akan komitmen perusahaan terhadap penerapan good corporate governance. Hal ini akan membantu perusahaan memperoleh dana segar dalam rangka mewujudkan target produksi sebesar 80 juta ton per tahun.

2. Mengembangkan dan melakukan IPO terhadap anak-anak perusahaan agar mendapatkan dana baru yang akan digunakan untuk melakukan akusisi berikutnya.

3. Untuk saran bagi peneliti berikutnya yang akan membahas valuasi saham agar dapat mengumpulkan data-data spesifik perusahaan terutama mengenai strategi pertumbuhan perusahaan dimasa depan melalui wawancara langsung dengan pihak perusahaan. Hasil dari wawancara tersebut akan lebih memaksimalkan asumsi peneliti dalam melakukan forecasting. 


\section{DAFTAR PUSTAKA}

Asteria, T. H. (2011, September 27). Prospek sektor batu bara di mata analis. Diperoleh dari http://pasarmodal.inilah.com/read/detail/1778935/prospeksektor-batu-bara-di-mata-analis

Asosiasi Pertambangan Batubara Indonesia (APBI). Statistic Batubara. Diperoleh dari http://www.apbiicma.com/index.php?option=com_fabrik\&view $=$ coalprod\&list $\underline{\mathrm{id}=5 \& \text { Itemid }=794}$

Bank Indonesia. (n.d). Bagaimana bekerjanya kebijakan moneter?. Diperoleh dari http://www.bi.go.id/web/id/Moneter/Transmisi+Kebijakan+M oneter/

Benaji, R. M. (2011). Valuasi nilai wajar saham perum pegadaian terkait rencana ipo tahun 2012 dengan metode discounted free cash flow to equity. (Tesis tidak dipublikasikan). Jakarta : Universitas Indonesia.

Damodaran, A. (2002). Investment valuation : Tools and techniques for determining the value of any asset $\left(2^{\text {nd }}\right.$ ed.). New York : John Wiley \& Sons.

Damayanti, D. (2012). Indusrty up-date. Jakarta : Bank Mandiri.

Dabu, P. (2012). Kontrak pembelian batubara pln lampaui kebutuhan. Kontan. Diperoleh dari http://industri.kontan.co.id/news/kontrak-pembelian-batubarapln-lampaui-kebutuhan

Dividend discount model-ddm. (n.d.). Investopedia. Diperoleh dari http://www.investopedia.com/terms/d/ddm.asp\#axzz1v8pJwxi $\underline{\mathrm{W}}$

Energy Information Administration (EIA). Annual Energy Outlook 2012. Diperoleh dari http://www.eia.gov/

Hauriah (2008). Analisa nilai intrinsic saham pt medco energy. (Tesis tidak dipublikasikan). Jakarta : Universitas Indonesia. 